\title{
Etty Hillesum: Esse quam videri - Reformed Christian perspectives on a spiritual journey
}

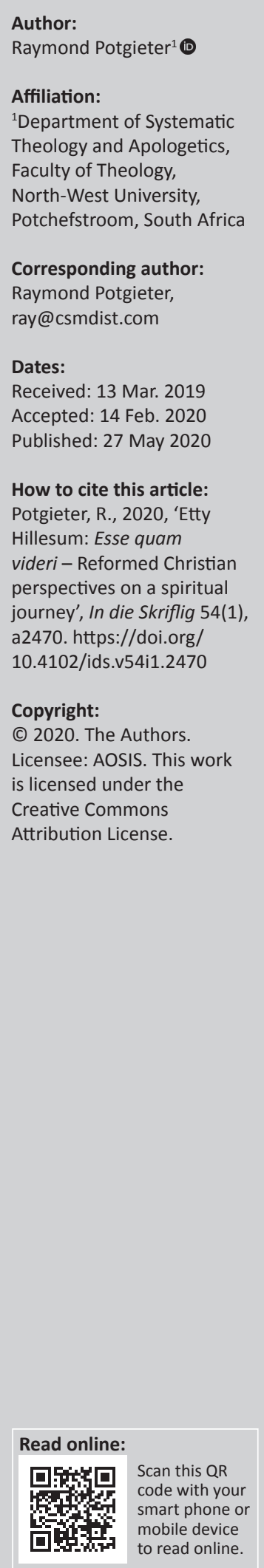

Etty Hillesum, known as the adult Anne Frank, diarised her emotional and intellectual journey from 09 March 1941 to 15 September 1943, a final postcard thrown from the train en route to Auschwitz from Westerbork transit camp. Her diarising initially aided her therapeutically to analyse her personal feelings rationally. But the changing circumstances in the Netherlands, due to the Nazi occupation in addition to her own turmoil, turned her diarising into a highly personal inner conversation. She initially addressed herself. As her conversation deepened, it took on the semblance of a two-way conversation. Hillesum eventually concluded that she was conversing with God. Her life became more meaningful as she adopted a New Testament servant mentality and attitude of forgiveness towards her Nazi enemies. It was this attitude that compelled her to serve the younger women of Westerbork transit camp, but also to tell them of God's power in forgiveness and hope for the future. This study will attempt to show Hillesum's place within Reformed theological thinking. This is a necessary exercise, as many people do not only drift away from the church, but do not turn to it or to Christian ministers for pastoral assistance in matters of the spirit.

Keywords: Etty Hillesum; Westerbork; diary; Auschwitz; transit camp; Reformed theology.

\section{Introduction}

Influenced by the writings of Elie Wiesel, the Christian philosopher of religion, John K. Roth (1997:198-199), wants theological reflection to relate directly to and within the context of real events. Should this premise be accepted, then the Holocaust has to be seen in the context of history together with the involved dynamics which shaped and continues to shape contemporary Jewish history. It is in light of this statement that this article will develop. The scale will, however, be far less ambitious.

Much is made of the concept of $\operatorname{God}^{1}$ after Auschwitz. Holocaust or Shoah ${ }^{2}$ views often debilitate or adjust traditional faith in the God of traditional scriptural (Tanakh) ${ }^{3}$ belief. This article seeks to develop some insight into the diarised personal experiences of God by a single Jewish woman, Esther (Etty) Hillesum - sometimes referred to as the 'adult Anne Frank'. The reason for choosing to explore her seeking and engagement with deity is the remarkable manner in which this was recorded in her diary and letters (Hillesum 2016) covering the period 1941-1943. Remarkable, because her emotional and spiritual journey did not follow the traditional Jewish or Christian confessional or catechetical understanding of salvation. Rather her emotional journey developed into a personal spiritual journey which eventually concluded with an objective perception of and a relationship with God. To all intents and purposes, this was the God of the Old Testament (Tanakh), although she (Hillesum 2016) concludes liberally with insights from the New Testament. But this view of Etty Hillesum's spiritual journey is not without opposition. ${ }^{4}$

Hillesum's diary is more than a collection of thoughts. It is an intimate insight revealing a private world, expressed in diverse personal and intimate relationships, but consistently coloured by the record of her Jewish background. For that reason, her diaries record the complexity of what it meant to be a Jew within the context of the events of World War II, but more particularly, as they impacted the Netherlands and her hometown Deventer and Amsterdam. Her diarised accounts reveal increasing religious struggles, as she tried to make sense of the brutal consequences of Nazi

1.A theodictic theme based on Holocaust insights has been developed as a heuristic device by Jewish and Christian theologians alike (McClelland 2004:187-188).

2. Holocaust (Gk. Holos + kostos = totally consumed or burnt) is the more popular term, but not favoured by Jewish scholars, because it is associated with sacrifice. Shoah or HaShoah is preferred, as it refers to catastrophe, calamity or destruction, for example Zephaniah 1:15. Israel celebrates the annual Memorial Day as Yom HaShoah on the 27th day of Nisan.

3. An acronym for the Old Testament comprising of the Torah (Books of Moses), Nevi'im (prophets) and Ketuvim (writings).

4.See for instance, McDonough (2005) for a variety of views critical and supportive of Hillesum's spiritual journey. 
occupation, including reflections on racial discrimination, struggles to maintain living with fear, hatred and antisemitism. She has questions without satisfactory answers which inevitably led to even more questions, but of a metaphysical nature such as the meaning of life, God and purpose of life after the war.

Patterson (2004) rejects the view that Hillesum's diary gives an account of seeking engagement with the Jewish God, arguing that her diary is narcissistic and more Christian than Jewish. Langer (1995:69-73) concurs, suggesting that Hillesum's responses to Judaism were not representative. It was, in fact, out of touch with reality and so failing to distinguish between the idea and experience of suffering. Brenner $(1998 ; 2008)$ admits that Hillesum's diary is neither typical of a Holocaust diary, nor is there evidence of a strong affinity with Jewish culture. The reason? Seen within the context of the Netherlands, during World War II, she (Brenner 2008) says:

Like most assimilated Western European Jews, Hillesum was undeniably steeped in the culture of Christian Enlightenment, and in this sense the diary provides a response of a Western Jewish intellectual to the Nazi terror. (p. 239)

This is thus suggestive of a weak view of religion (Jewish faith or Judaic religious system) with a penchant to resort to reason rather than faith, to explain life's critical moments.

A cursory background of the Hillesum family's way of life and that of Etty Hillesum will be a useful introduction to the content of her diary. Progress of her search for inward peace and meaning of life $^{5}$ reflects some of her most intimate thoughts as these pertain to her Jewish family, but also to her own Jewish identity. All the while in dealing with these questions there remained the ever-increasing dread of the German solution to the Judenfrage. ${ }^{6}$

An overview of her diaries and letters reflects her subliminal passage from pre-occupation with self, to a perception of the subjective place of God in the context of living and imminent dread. This eventually concludes with her embracing God objectively. In a seemingly New Testament manner, she commits herself to a ministry to service fellow young Dutch Jews women at Westerbork ${ }^{7}$ transit camp in Drenthe province on their way to death camps. In other words, there is evidence that she underwent a transition from being preoccupied with her inner subjective struggles, to gradually centre objectively in the One in whom all things conclude. Her engagement towards and with God, will be subjected to some critical

5.Viktor Frankl (1992), who survived Auschwitz, observed the debilitating effects of hopelessness upon inmates who suffered a lack of meaning and thus a reason for living in the death camp. These are observations which led him to develop his logo therapy.

6.Even Bonhoeffer regarded the Jews as a problem and that their civil rights could be denied (Ericksen 2012:37)

7.Breslauer's film (May 30, 1944), one of only two films portraying the inside functioning of a concentration camp for Jews. It portrays a propaganda façade of Westerbork (near Assen), which in reality, actually served as a highly efficient transit Westerbork (near Assen), which in reality, actually served as a highly efficient transit
camp (Durchgangslager) which saw the exportation of more than a 100000 Jews exported to death camps. comments reflective of a stated Reformed Christian perspective of theology. Finally, this article will also attempt to, from the same perspective, place Hillesum within a context consistent with the Reformed Christian faith.

\section{Brief overview of the culture of Enlightenment in the early 20th century and the Nazi occupation of the Netherlands}

Farbstein (2007:11-12) cautions that terms such as ultraOrthodox, Haredi and Orthodoxy must not be used as representative classifications for Jews of the time before World War II. Taxonomies of this nature simply do not fit. When it came to rabbinic training, a more traditional theological classification used, was the story of Jacob and Esau. The story was portrayed as being illustrative of the purported intense hatred that Gentiles harboured against Jews throughout their history (Farbstein 2007:55). Nevertheless, changes were afoot in Western Europe. Seeds of change were already endemic before that in the early 20th century. A new life and worldview were in the making. ${ }^{8}$

With European economic prosperity came an influx of Jews into Europe. They came, in the main, from Eastern Europe (Ashkenazi) and further afield (Sephardic) seeking to share in the progress and prosperity that characterised Europe in the 19th and early 20th centuries (Hyman 1998:25). For centuries, Jews were unique in that they were a people without a country and yet retained their identity. But changes were afoot. Many of these immigrants discarded or realigned their arcane views of Jewish religion, regarded as outdated and even irrelevant. The Latin word relig means 'to bind' and traditionally implied cohesion of a community. But for many at the time, religion rather evoked suspicion as the historical cause of conflict and division, and is thus suggestive of incoherence and disintegration.

Many Jews even professed conversion to Christianity. It was often a utilitarian move, allowing for acceptance among influential Christian circles, as 'Christianity created Western Civilization' (Stark 2005:233). A modernised Judaism came about with the emphasis on retaining Jewish identity, but not necessarily that of religion, the seeds of Zionism. By the 1920's, Jews:

$[F]$ or the first time in their history ... were recognised as citizens in every country in which they lived. Especially in Western Europe and the Soviet Union, an ambitious, meritocratic middle class was rapidly climbing the social ladder. The best-educated ethnic group in Europe, Jews shone in all fields of science, dazzled in the theatre and literature, and constituted the beating heart of musical life. (Wasserstein 2012:xvii)

8.Stark (2005:x; cf. Amsterdam 144-147) glosses over the usual arguments such as capitalism, Protestant Reformation and political circumstances in discussin 'Europe's great leap forward'. Instead, he suggests that 'the rise of the West was an 'Europe's great leap forward. Instead, he suggests that 'the rise of the West was an extraordinary faith in reason'. Even a cursory reading of Hillesum's diary (2016) testifies to unmistakable spirit of the age and thus the role of reason, which I would suggest, for Hillesum also took place within a Judaistic framework. On the othe hand, the Calvinists, Groen van Prinsterer and Abraham Kuyper, saw the unfolding of the 19th and early 20th centuries as a reaction to the French Revolution opening the door to socialism, secularism and agnostic idealism (Praamsma 1985). 
But that was not to last.

Adolf Hitler came into power. By 1933, German and Austrian Jews were fleeing from increasingly inflammatory antiSemitic $^{9}$ rhetoric of political scapegoating. Many Jews began arriving in the Netherlands as refugees. They came with their own cultural baggage. Many held to Enlightenment views on issues such as gender, family, and a lesser commitment to traditional Jewish religion (Hyman 1998:25-38), and for those reasons, a diminished reliance on Rabbis for counsel. These new refugees were often perceived as loud and arrogant, lacking in appreciation for the efforts of Dutch Jews attempting to ease their lot. Dutch leaders began to speak of a 'Jewish problem' (Judenfrage). ${ }^{10}$ To that end, by 1939, the Dutch government built Westerbork camp in Drenthe province in North-East Netherlands. It was to serve as a temporary centre to house and provide skills training for refugees.

In May 1940, the Austrian Nazi, Artur Seyss-Inquart, the Reichskommissar in the Netherlands said:

The Jews, for us, are not Dutch. They are those enemies with whom we can come to neither an armistice not to peace. The Führer declared that the Jews have played their final act in Europe, and therefore they have played their final act. (Friedman 2004:108-109)

Soon, forms of Aryan attestation were implemented in the Netherlands in a systematic manner, and by the end of 1940, businesses and some 160820 individuals were identified to be Jews. By 1942, the German occupiers ${ }^{11}$ used Westerbork as a fulltime Jewish Durchgangslageren route to death and concentration camps ${ }^{12}$ in Germany and Poland (Foray 2001:333). These deportations started in the summer of 1942. This background and time frame bring us to the recordings of Etty Hillesum's diaries.

\section{Etty Hillesum, the young woman and her spiritual journey}

Esther Hillesum (15 Jan. 1914) was born in Middelburg, Zeeland in the Netherlands to Dr. Louis and Rebecca (Bernstein) Hillesum. Known as Etty, she later stayed in Deventer, Overijssel. Her Dutch Wartime Card File for Jews, number 1.2.4.2, states her religious affiliation in the category

\footnotetext{
9.From a Christian perspective anti-Semitism is basically the failure to express Jesus fundamental teaching of love towards one's neighbour (Mt 22:39). Arendt (1962:454-455), on the other hand, interpreted Nazi anti-Semitism as the (1962:454-455), on the other
outworking of their ideology.
}

10.Zionism was, for instance, mooted as a modern option to the Jewish question.

11.When German forces arrived in May 1940, the Dutch government capitulated and fled. With that came the systematic implementation of strictures implemented by Reichskommissar Arthur Seyss-Inquart. For instance, kosher butchery was soon prohibited, the 'Aryan Declaration' necessitated all Jews in civil service to declare their status, and the Bureau of Economic Investigation began to appoint German and Dutch Nazis to 'administer' Jewish owned businesses (Foray 2001:334). Capitalisin on the fact that Westerbork was a well-known and accepted holding work or training camp, which even housed a hospital, orchestra, restaurant and other amenities, the camp, which even housed a hospital, orchestra, restaurant and other amenities, the camps elsewhere. Westerbork was liberated on 12 April 1945.

12.Mainly Auschwitz and Sobibor, but also to Bergen-Belsen concentration camps. Those sent to Theresienstadt (ghetto) either died there from malnutrition, disease or inhuman treatment, or continued the transit to death camps (Chelmno, Belzec, Treblinka etc.) elsewhere. 'bijzonderhoden: ${ }^{13}$ liberaal' (Yad Vashem). ${ }^{14}$ This 'liberal' tendency is also reflected in her diaries. What is manifestly clear is that Hillesum was never an 'onderduiker' [literal translation: dive under in a covert sense]. ${ }^{15}$ She never tried to hide the fact that she was a Jew.

By the time Etty starts diarising ${ }^{16}$ on Sunday, 09 March 1941, she was 27 years old. But her diarising must not only be seen as reflecting her present experiences, but also the context of her age. From her first diary entry the reader is aware of her personal complexity reflected by her relationships with various people. These included her parents, friends, lovers, and the German invaders of her country and town. Woven into her accounts are the mixed emotions and fears she experienced and her desperate search to determine how to personally overcome emotions such as hatred, meaninglessness and so on.

One of her lovers was her psychoanalyst, Dr Julius Spier (Mr S. or Ju). The other (her first) was Hendrik (Han) J. Wegerif in whose house she served 'as a sort of a housekeeper' (Hillesum 2016:xix). When Hillesum met Spier, he was divorced and betrothed to a woman in London. He had particular influence on Etty. It was he who advised her to keep a diary for therapeutic purposes.

What becomes clear from the diaries is the progress she made. Initially, she was virtually totally reliant on Spier for psychological counsel, the intensity of which was exacerbated by their physical and personal relationships.

But the diaries reveal even more. Hillesum's emotional turmoil took on the semblance of a journey of subjective discovery. Psycho-analysis helped her, in onion-like fashion, to strip or peel away layer after layer of personal emotional and intellectual baggage as she delved deeper into herself. Not only was it a journey which had her wrestling with deep questions pertaining to the meaning of life, it also led to a discovery of herself as a human being created in the image of God. As Hillesum $(2016: 38,153,214)$ became aware of her inner and cosmic space, she began to acknowledge the real existence of the Creator intellectually and relationally. Later, she was to apply the same peeling away process in her ministry to the young women she engaged in her ministry at Westerbork. Peeling away prejudice, anger at God, barriers caused by hurt and so on, until Hillesum could speak to them about their Creator God whose image they reflected.

13.The category on Etty Hillesum's card does not capitalise the ' $\mathrm{b}$ ' of bijzonderhoden. The 'liberaal' on her card signified Jewish identity and not commitment to Jewish traditional religion.

14.Yad Vashem was the World Holocaust Remembrance Centre which I visited in 2018 I accessed Hillesum's original Dutch Wartime Card from the Yad Vashem files, namely 'Wartime file of the Jews in Holland', Reference code: 4080000, 1.2.4.2. Dutch Wartime Card File for Jews, Esther Hillesum, category, 'bijzonderhoden: liberaal' with transport dates to the transit camp Westerbrok and from Westerbrok to various $\mathrm{KLS})-25.1 .1949-$

15.'Onderduiken' (Foray 2001:338), in fact, was a national phenomenon. Some 20000 to 30000 Dutch Jews hid from the Nazis during the war years of whom about 16000 to 17000 survived the war.

16.The Hillesum and Philip Mechanicus (1968) diaries are taken as acceptable Holocaust literature, while that of Anne Frank tends to be seen as: 'a childish version of "adult fare"' (Foray 2001:341) 
Another example of a Dutch person who also found God during that time was Hans Rookmaaker ${ }^{17}$ (1922-1977) (2003). He later expressed his Christian perspective of God and his reign during the same period of occupation:

\footnotetext{
... I was a prisoner of war. In a time of war, I discovered, we are not afraid, for God is working. In the end, good will win. The 'thousand year Reich' would eventually fall, as would all other future terrors. (p. 70)
}

Hillesum's diaries were entrusted to Maria Tuinzing, with the request that they should be offered for publication by Klaas Smelik, in the event that she did not survive her deportation. Chronologically, this article covers a timeline as recorded in her diary in March 1941, until her final postcard postmarked 15 September 1943.

\section{Discerning a theological pattern of Etty Hillesum's spiritual journey to conclude with God}

\section{A journey toward and with God}

From Etty Hillesum's initial diary entry on 9 March 1941 to July 1942 (2016), there is a discernible thread documented which allows for insights into her emotional and spiritual journey - especially evident in her coming to a spiritual understanding, expressing faith and reason in her relationship with God. This diarised 15 month journey was not easy and clear-cut. Rather, it was characterised by an eclectic meander with little resemblance to the customary expected cathectical or confessional progression towards spiritual maturity. Although not overtly religious in terms of Judaism's system rituals, her diaries reveal that her emotional and intellectual journey took on a discernible spiritual pattern. This manifested most evidently in her engagement with a variety of personal subjective and indistinct concepts and imageries of God, which were mostly estranged from biblical understandings of God. Nevertheless, Hillesum eventually concluded with a more objective and personal formulation of God. Her understanding matured the more she engaged with the Bible as a whole.

Various opinions have been expressed regarding similar spiritual or religious journeys akin to Hillesum's relationship with her inner self, god, God or concept of the divine - a struggle between divine transcendence and immanence. One such journey was that of Katherine Mansfield $(1888-1923)^{18}$ '... and I, too, feel that I don't want a God to appeal to - that I only appeal to the spirit that is within me' (1988:193). Mansfield's journey would not have satisfied Hillesum. Her questions required, even demanded, more than speculative answers. Augustin's resort to meditation (1886:308) might have been more akin to her own: '(On) my

17.Former prisoner of war, interned in various camps from 1942 to 1945 (Rookmaker 2003:414)

18.This was the pen name of author, Kathleen Mansfield Beauchamp, who died from extra pulmonary tuberculosis (Mansfield 1988:122). I found a number of similarities shared by Etty Hillesum's and Katherine. I found a number of similarities shared by Etty Hillesum's and Kat28) whe Mach to living and seeking after ', her 'my Eternal Question', matters of health, issues arising from her affairs, loss of close acquaintances to death, facing the inevitability of her own death and so on. do not explore these shared similarities here. Mansfield also died prematurely at the age of 34 . bed I meditated long, and talked thus with myself Augustin addressing and answering Augustin'. Hillesum struggled to emerge from her emotional subjectivity and to relate meaningfully and intellectually to the reality of the experiential - her living. For her, the test was whether the answers she was gleaning could withstand the reality of the changing circumstances which Jews were subjected to by the Nazis' occupying the Netherlands, and in particular, her home town, Deventer. ${ }^{19}$

While a most intimate and subjective conversation satisfied Hillesum for a while, gradual habituation brought about change to her predominantly inner journey revealed in her diarising. Through a diminishing dependence on stimuli, which characterised this inner journey, she began to engage with God, the meaning of life, God as the One who unfolds history, the role of survivors after the war, and so on.

Bearing in mind that we are dealing with someone who was raised a-religious, nevertheless, in my opinion, it is possible to trace her spiritual journey along the following lines: Hillesum's inner subjective conversation concluded with an emergent consciousness of deity. She concluded that all human beings must be created in the image of the Creator, which she interpreted in a generic sense, namely that there is something of God within each person. Consequently, even the enemy (Nazis or Germans) shared in that image. But the image of God is obscured in all persons which she likens to darkness that needs to be peeled away so that each one could meet with God, even in death camps. That unpeeling of the layers obscuring God and to finally present him to persons, became her mission. Meeting with God allowed for hope. Circumstances forced Hillesum to project that hope into an ideal future - one in which all would be able to share in a new world in which God is not obscured, as the memory of past horrors would prevent survivors to educate future generations of the atrocities possible when God was obscured.

See the bibliography below for authors who trace her life journey from perspectives other than the spiritual.

What now follows is a more detailed sketch of selected ways that Etty Hillesum followed which led to her meeting God, and finally, death together with the people she committed herself to serve.

Hillesum's diarising revealed a conversation: From the outset, it is clear that Etty's diarising engages in personal conversation with herself.

I seem to be a match for most of life's problems, and yet deep down something lies, a tightly wound ball of twine binds me relentlessly, and at times I am nothing more or less than a miserable, frightened creature, despite the clarity with which I can express myself. (From Hillesum's diary, 09 March 1941 to 15 September 1943.)

19. Hillesum often stayed in Amsterdam too. Westerbork camp was about $85 \mathrm{~km}$ from Deventer and some $184 \mathrm{~km}$ by road. A distance of a $107 \mathrm{~km}$ separated Deventer and Amsterdam. 
In her seeking to unravel the 'ball of twine that binds', she asks questions and seeks the answers. But is that enough? Gagné (2000:1-2), writing for Christian readers, is of the opinion that women are handicapped by the image of God as Father and Judge. For that reason, Gagné argues, this obscures the image of God for women which may, from a Jungian perspective, serve to understand Etty Hillesum as 'a modern-day divine child or psyche' - the possibility of transcendent love becoming manifest. Whether one agrees with Gagné or not, one thing is clear, she interprets Hillesum's spiritual journey in terms of a meaningful relationship with the transcendental. Coetsier (2010:105) is of the opinion that there are authors who 'emphasise Hillesum's influence on feminism and humanism rather than reflect on her spiritual side'. In other words, they choose to reflect on matters other than her spiritual journey and her engagement with God. These comments imply with some conviction, that it is clear from Hillesum's diarising that God is being engaged at all levels of her being.

From the aforementioned, it should be clear that it is possible to glean some understanding of Hillesum's comprehension of the God concept. This God concept matured from an immature subjective concept to take on an objective quality which she, in time, identified as the Creator God. It was not a final or conclusive comprehension of God, but did evidence a sense of the Old Testament God as Creator of reality and of humankind in his image in seeming control of history. ${ }^{20}$ At the same time it also did resemble the incarnate Son of God when it came to considering meaningful engagement, giving expression to the meaning of life. This would include sharing in the image of God together with your enemy necessitating Christian forgiveness and love of one's enemy, serving God (women in Westerbork) through serving others.

Etty Hillesum's eclectic reading: Hillesum $(2016: 16,125,164)$ read widely but selectively. By 26 May 1942, she could testify about the comfort her wide reading of the classic writers (Hegel, Rilke, Dostoyevsky, Jung) and Augustine as well as the Apostles. While she spoke about the authors as if they were present (De Costa 1998:149), they brought her to the realisation of man's past and present atrocities. According to De Costa (1998:141), Hillesum resisted the zeitgeist of death and destruction, and sought for that which would be lifeaffirming; her reading prevented her from concluding that life is meaningless. While the Nazi occupation of the Netherlands developed into more overt methods of dealing with the Jews, her frequent resort to reading the contemporary classics allowed her to encounter their characters. Basically she sensed that all the great poets and writers were instruments of God and worthy of thoughtful reflection. Implicitly, she adopted forms of resistance and so developed a rudimentary survival mechanism. Despite humanity's atrocities reflecting so little of God's image by which they were created, she (Hillesum 2016:165-166) was able to face

$20 . H i l l e s u m$ struggles with comprehending God's control of history which she interpreted to include historical events (World War II mass destruction of Jews) interpreted to include historical events (World War II mass destruction of Jews), directing humankind and individual lives. She (Hillesum 2016) at once questioned God's seeming helplessness, limitations or failure to do so adequately and, for that reason, redirected the blame to human beings who obscured God within them. reality realistically. At no time, however, did Etty Hillesum (2016:155) compromise her Jewish identity. Nevertheless, she had no qualms in, for instance, engaging in meditating on the service of New Testament's priestly mediation between God and man, as she (Hillesum 2016:173) pondered on the meaning of 1 Timothy 2:5. She read this by implication. She had to have engaged to some extent with the 'one mediator between God and men, the man Christ Jesus who gave himself as a ransom for all men', although she relates it in the context of Spier's selfless commitment to his patients.

Etty Hillesum and the Bible: Her (Hillesum 2008:29-30; cf. footnote) first overt mention of reading the Bible was on 8 May 1941, which probably resulted from the unexpected suicide of her professor and eventual friend, Bonger. But a month later, Hillesum (2016:33) was not confident enough to settle on the meaning of the Bible gleaned from her reading of the book. She (Hillesum 2016:30) began to ponder on how to face the fullness of reality - to live fully inwardly and outwardly, so as not to neglect the one at the expense of the other. She resorts to a dual concept of reality: outer and inner worlds. Spier did read the Bible and excerpts from Thomas à Kempis to her, but they failed to actually have any in-depth discussions together (Hillesum 2016:32). That seemed to change (Hillesum 2016:198). By 24 April 1942, Hillesum $(2016: 148,149)$ is reading the Bible regularly and soon the Psalms became 'part of my daily life'. In preparing herself for the camp ordeal at Westerbork, she (Hillesum 2016:224) followed Dostoyevsky's example who, in his 4 years in Siberia, was never without a Bible. Similarly, in Westerbork, her hand often rested on the open Bible. There is a strong indication that she (Hillesum 2016:261, 396) was regularly reading the New Testament, Matthew and Pauline epistles. By that time, on 24 March 1943 , it was part of her life. It took precedence over Rilke and was as food to her soul (Hillesum 2016:208-209, 214, $256,318)$. Even her father read the Bible fervently in Westerbork (Hillesum 2016:333, 351). Exiting Westerbork in the cattle car, she opened the Bible at random and read Psalm 18:2: 'The Lord is my high tower', which encouraged her (Hillesum 2016:426) and the young women she had charge of to sing hymns of praise.

Etty Hillesum's inner and outer spiritual journey: Her assessment of her mixed and confused emotions ${ }^{21}$ due to her physical, emotional and cerebral relationship with Spier, brought her to a point of needing to stabilise herself. Persuaded that a human being is body and spirit, she (Hillesum 2016:33) turned 'inward ... (to) listen to my inner voice'. A 'quiet hour' was, however, not so easily negotiated. She quickly recognised impediments within her that needed to be removed, before God and 'something of Love' could enter the innermost being. She resorted to reading some philosophical meditations. But what must be observed, is the manner in which her inner engagement takes on the

21.Hillesum $(2016: 85-88)$ describes the process of aborting her unwanted child, while at the same time, engaging in two separate affairs (cf. De Costa 1998:148). 
semblance of conversation: 'You keep saying that you want to forget yourself completely my girl' (Hillesum 2016:34).

Perseverance, however, paid off. It was Rilke who taught her the value of inner reality - so much so, that it began to mean more to her than surface existence (De Costa 1998:151). From the Bible she began to glean the possibility of meaning to life. But even more significantly was that it allowed for experiential reality. She brought biblical truths together in, for instance, associating being created in the image of God makes loving one's neighbour possible (Hillesum 2016:81). In time, Hillesum realised the role of prayer in her own life. Although she struggled to pray, she was eventually able to say, 'Oh, Lord, let me feel at one with myself. Let me perform a thousand daily tasks with love ... Then it won't really matter what I do and where I am' (Hillesum 2016:85). By December 1941, Hillesum (2016) prays:

Oh God, I thank You for having created me as I am. I thank You for the sense of fulfilment I sometimes have; that fulfilment is after all nothing but being filled with You. I promise You to strive my whole life long for beauty and harmony and also humility and true love, whispers of which I hear inside me during my best moments. (p. 90)

Negotiating her Bible reading was, however, no easy task, 'I ... am trying to make sense of it all' (Hillesum 2016:92).

When Spier remarked that 'You live too cerebral a life' (Hillesum 2016:265), it led her to further evaluate the value of prayer in her life. Prayer allowed her to refresh herself meeting with the 'original source' of prayer. She (Hillesum 2016:265-266) rested herself in prayer and enjoyed the renewal of her personal strength, the resolve to serve God and so enjoyed the accompanying peace of seasons of withdrawal in prayer.

What struck Hillesum (2016:90) was the struggle Spier ${ }^{22}$ overcame to summon 'The courage to speak God's name'. Reading the Gospel of Matthew, she moved from the woman who could not kneel to being filled with the urge to kneel and pray (Hillesum 2016:132, 133). In due course, Hillesum also influenced Spier's religious beliefs ${ }^{23}$, and in particular, his understanding of Christianity. Hillesum was to experience in increasing measure what it meant to externalise her inner convictions as a believer in God. 'I keep talking about God the whole day long, and it is high time that I lived accordingly' (Hillesum 2016:263).

This was a change which began to manifest overtly as a personal directional change, so that by July 1942, God was central not only in her life (Pleshoyano 2010:72), but in her very thinking and expectation of the fulfilment of living. In that month, she volunteered to work with young women in Westerbork. On the other hand, a more feminist approach is also mooted.

22.Spier seemed to have a pantheistic view of deity. See his comments to a patient about St. Matthew's Passion in Hillesum (2016:90).

23.Spier learnt about Christianity from a patient, Adri Holm (1910-1970), even before he accepted Hillesum as a patient (Hillesum 2016:5 footnote). Someone once said of Spier, 'There is something of the Early Christian about you' (Hillesum 2016:120).
In spite of being employed by the Jewish Council 'Sociale Verzorging Doortrekkenden' on 22 July 1942 and 8 days after Spier's death (on 15 September 1942), the sickly Hillesum ${ }^{24}$ still found the strength to testify of the Christian way of love in dealing with one's enemy. Insightfully, she argued for the eradication of hatred in society by first eradicating it within one's own heart. Startled, the communist, Klaas Smelik (1897-1986), exclaimed, 'But that - that is nothing but Christianity!', to which Hillesum (2016:259) replied, 'Yes, Christianity, and why ever not?' This must, however, be juxtaposed by her prayer the day after her appointment on 15 July 1942 at the Cultural Affairs Department of the Jewish Council: ${ }^{25}$ 'Have You any other plans for me oh God? Tomorrow I must betake myself to hell (Westerbork)' (Hillesum 2016:223). Life had taken on meaning beyond herself; she had entered into the larger maelstrom of life - the one which historians would later reflect on.

On the other hand, while recovering in Amsterdam, knowing that she will inevitably have to return to Westerbork by 08 October 1942, Hillesum was able to see the beauty of life. Her faith in God led her to a new dimension in the meaning of life: 'I want to be there right in the thick of what people call "horror" and still be able to say: life is beautiful' (Hillesum 2016:276). In Westerbork, assisting screaming children from the cattle cars to be deloused, carrying heavy baggage for weary transporters, she faced the questions from helpless women: 'Could you tell me, please could you tell me, why we Jews have to suffer so much? ... I keep calling, "O God, O God" but does He really still exist?' (Hillesum 2016:327).

Hillesum's overt ministry to the women in Westerbork took on various forms. She saw each individual as having the potential to have God dwell in them as he dwelled in her own heart. Collectively, these women were 'bundles of misery' in whom guilt existed as obstacles that keep God away from them. She (Hillesum 2016) phrased her ministry in unusual terms:

I promise that I shall try to find a dwelling and a refuge for You (God) in as many houses as possible. There are so many empty houses, and I shall prepare them all for You, the most honoured lodger. Please forgive this poor metaphor. (p. 250)

This is explained from the relief she experienced, as Spier used psycho-analytical techniques to peel away layer after layer of confusion to eventually reach her innermost depths. With this insight, she sought to peel away the layers of hurt, confusion, despair and more from the people she ministered so that they would find God unencumbered by any distraction. That meeting or discovery was key to understanding Hillesum's continued ministry to the people in Westerbork. They needed to meet with God. On 15 September 1943 (Hillesum 2016:426, 429), bundled into

24. Her illness allowed her to return to Amsterdam for three months at the end of August 1942.

25.By 25 July 1942 Hillesum (2016:234) wrote, 'God save me from one thing: don't let me be sent to a camp with the people with whom I now work every day.' She was neither cut out for the monotony of office work, nor for the chaos and misery, and the ineptness of the people she worked with to manage the office. 
wagon $12^{26}$ with her little Bible and other items and with a thousand 'transport cases', she wrote: 'We left the camp singing.' The reference to the Psalm mentioned in her postcard, was according to Brenner Psalm 18. Her beliefs remained intact to the very moment of departure despite the suffering and terror (Brenner 1998:24).

\section{A Reformed evaluation of Hillesum's theological struggles and conclusions \\ A Reformed theological baseline}

Any spiritual journey with some substantive claims referring to the Bible, either Old or New Testament or both, must allow for, among others, theological scrutiny from Christian theologians. To that end, the following: Reformed theology is most clearly expressed in its confessions and catechisms. For the present a catechetical distinction will be useful. The ecumenical Heidelberg Catechism $1563^{27}(\mathrm{HC})$ posits its first of 129 questions as: 'What is your only comfort in life and death?', which demands the response of ownership in toto to 'my faithful Saviour Jesus Christ', based on his works alone. On the other hand, the Westminster Shorter Catechism 1648 (WSC) asks: 'What is the chief end of man?', which is succinctly answered in precision of language as 'Man's chief end is to glorify God and to enjoy him forever'. This is the first of 107 questions. While the HC promotes Christian comfort and joy, the WSC pursues the glorification and enjoyment of God. Both questions and answers reflect, to a greater or lesser degree, the pastoral sense in which the catechisms were formulated. Historically, these catechisms have borne the tests of biblical scrutiny in their systematic arrangements and formulations of questions and answers pertaining to biblical doctrines and Christian practices, and consequently teach the same doctrinal system.

Both catechism questions challenge enquirers to selfexamination and to consider answers that supersede speculation and abstraction arising from philosophical, metaphysical, psychological and material answers. These first questions set the benchmark for the questions and answers that follow. A mark of both catechisms is that they are inherently reliant on special revelation and the historical teleological discernible plan of God for mankind and creation. But the question for this article, is the following: How would Etty Hillesum fit into this doctrinal systematisation and discerned Christian practice? In my opinion, she would not.

But something must be said about the appreciation of subjective observances and struggles. This is the appropriate place for a caveat. Subjective experiences are not to be denigrated through some mechanistic, materialistic or predominantly rational view of theology. Kierkegaard (1968:181) famously claimed that it may be argued at times that: 'subjectivity becomes the truth'. Wynn (2005), taking the 26.She died in Auschwitz on 30 November 1943

27.To name but one of the Reformed catechisms, which with the WSC, are best known and loved. latest developments of philosophical theology, psychology and neuroscience into consideration, developed a thoughtful treatise on the objective value of emotions. He (Wynn 2005:xi) states: 'emotional feelings can function as modes of value perception - in relation to God, the world, and individual human beings'. I suggest that much of this approach is clearly reflected in Hillesum's diary (2016).

Hillesum struggled comprehending God's control of history, including the unfolding of historical events (World War II and the mass destruction of Jews), failure or helplessness to direct humankind and intervene in individual lives. Although she questioned God's seeming helplessness, limitations or failure to adequately deal with matters of life and death, order and destruction, she redirected the blame without deprecating the Creator God, which is a theodictic matter. Nevertheless, she (Hillesum 2016:221), with some sense of fatalism, also wrote: 'We lack a historical sense, forget that even those about to perish are part of history. I hate nobody. I am not embittered.' Humans, created in God's image, have allowed God's image in them to become so obscured that he is no longer thought to even exist or at least care about the individual (Hillesum 2016).

Christian doctrine is Trinitarian by nature and integral 'it is the doctrine of God as a whole, in which God gives us a glimpse of His own inner life' (Frame 2002:735) - an integral message from God. Vorster (2007:162) is of the opinion that the completed message about God must reflect a New Testament approach in that it must be undergirded by a Christian perspective of biblical theodicy. Pain, despair and hope, naturally lead to questions searching for reasons for suffering. This puts the objective in stark relation to the subjective, but far from irreconcilable. Both finally meet in the historical event of what Jesus accomplished on the cross. In other words, the meaning of suffering is not sought in suffering itself, or in God's presence or absence, intervention or non-intervention, but in his revelation (Vorster 2007:159). Admittedly, there is no complete answer to be gleaned from the TaNaKh or the New Testament. But some attempt towards an answer, be it incomplete, is possible. Vorster (2007:160) says, 'No suffering can be meaningless, because all suffering has Christ as its telos'. Secondly, that all human beings are created in God's image and for that reason may identify with the works of God and ultimately with the person of Christ. It is clear from Hillesum's diary that she did explore suffering, and in the process of dealing with her hatred, discovered the illuminating truth that all persons, even the most hated enemy, share in the same image of their Creator God. Although her diary gives an incomplete comprehension of her spiritual journey, it must be borne in mind that she had but a fragmented and incomplete understanding of the theology of the Bible. Nevertheless, she did grasp the gist of some of its truths.

While the focus on the suffering Jews (and many others) during World War II may never be minimised, there is no theological reason to claim a continued uniqueness of the Jews as the chosen people or God's people, et cetera 
(Paas 2015; cf. Potgieter 2015). Neither is the failure to account for a rational explanation of God's non-intervention during the Holocaust, substantial reason to claim redefinition of the traditional God of Judaism and its fuller version in Christianity. Holocaust theology generally accepts that God may no longer be believed to be all-powerful and good. The metaphor is conveniently adjusted to suggest a limited God, more in keeping with some degree of process as developed by process theologians. ${ }^{28}$ This one-sided approach does not reflect a Trinitarian perspective. 'The doctrine of the Trinity is connected to a view of the Creator-creature relationship: God is not forced to relate to the world through semi divine mediations' (Frame 2002:734-735).

\section{Etty Hillesum's diarised journey with God}

While not every strain which influenced Etty Hillesum's journey to God was touched upon, the above should be sufficient to establish the differing, but intertwined dynamics of that journey. Walking with God must consciously start the journey, no matter the route 'there will always be a small patch of sky above, and there will always be enough space to fold two hands in prayer' (Hillesum 2016:221). The complexity of her spiritual journey is intertwined with personal issues, mingled with fear in her desperate search for meaning, her first steps in encountering God beyond a subjective conversation of self. With that as context, Hillesum's journey with God is now addressed.

\section{The transcendent and immanent God}

The objectivity of reason failed to categorise Hillesum's subjective experiences rationally, as she met in increasing measure with the transcendence of God. God transcended her experiences ${ }^{29}$ and consequently allowed for meaning in life (Hillesum 2016:35, 386) and hope (p. 186), which transcended her own mediations. It was sufficient to preach this message for those who would and would not survive the death camps. It also allowed for forgiveness and aesthetic appreciation (Hillesum 2016:17,395). But this must be read as issuing from Hillesum's personal feelings (2016) and her interpretation of the identity and place of God in her life:

I repose in myself. And that part of myself, that deepest and richest part in which I repose, is what I call 'God' ... as if I were lying in Your arms, oh God, so protected and sheltered and so steeped in eternity ... as if my smallest acts and words had a deeper source and a deeper meaning. (p. 249)

Hillesum used 'the most appropriate language to stammer out something of the impalpable within herself' (Pleshoyano 2005:225) - language that encapsulated metaphors and symbols reflecting something of the mysticism of her experiences.

\section{Holocaust theology and anti-semitism must be dealt with separately.}

29.The page references are deliberately spaced chronologically so that the development of Hillesum's awareness (2016:233) of the transcendent is made more evident. Sometimes it is the context of her God awareness which leads her, for instance to associate beauty and meaning while wrestling with her fear and high possibility of inevitable suffering.
Her relationship with God began to transcend the most intimate feelings of love for any person she knew: 'After all one can't pour the whole of one's love out over a single man, can one?' (Hillesum 2016:279). Spier, the God-seeker and God-finder (Hillesum 2016:246) had been supplanted by God, who now not only claimed the innermost space in her life, but infused it with meaning. With the ascendency of the immanent God in her life, the meaning of life transcended the horrific present. That meaning lay in the hope and responsibility incumbent on possible survivors of the terrible death camps. Nevertheless, her inward struggles remained, but not in the sense of hopelessness. Not even the paradoxical fact that 'hell' could be within her (Hillesum 2016:189) as it was without (pp. 187-188) as were the earth and sky, overwhelmed her. But Hillesum (2016:189) carried more than that within her: 'Yes, we carry everything within us, God and Heaven and Hell and Earth and Life and Death and all of history.' This insight was probably buttressed from her reading of the classic authors mentioned elsewhere. But it also reflect the Old Testament understanding of God being transcendent and immanent.

Hillesum never mentions any major feelings of guilt. There was seemingly no overwhelming feeling of sin about her continued relationship with Spier, nor did guilt about her attitude to overcrowding and her refusal to get involved, leave her feeling guilty (Hillesum 2016:150, 169). Yet, she does recognise that guilt blocks the way to God.

\section{God: the One who serves and is to be served}

Hillesum was captivated by Spier's counselling of patients. He did so through delving into his patients' innermost to reveal the hidden God, by gradually peeling away the layers of poisonous material that obscured him. It was this priestly manner of Spier which led Hillesum (2016:173) in her inner journey to discover God as Source, by whom 'the water of life begins to flow again in dried-up souls'. Apparently, Hillesum (2016:173) came to this observation through meditating on 1 Timothy 2:5: '[the] one mediator between God and men, the man Christ Jesus who gave himself as a ransom for all men'. This seems to be one of the key insights into understanding Hillesum's ministry from the latter half of 1942 to the end. She began to depend on the Word of God for purpose in her life, which led to her (pastoral) involvement with the young women in Westerbork en route to the death camps.

My opinion is, that shortly before her appointment by the Jewish Council, whether overtly conscious of the degree of her decision or not, she committed herself to a priestly ministry among young women in Westerbork. This was not her only ministry, but one which she pursued even to the extent of accompanying these young women to Auschwitz. She had already decided not to attempt to hide from the Germans. Already by 19 February 1942, her diary reveals that, based on the insights from the classics and the Bible, Hillesum (2016:103) concluded that the evil at work in every Gestapo was inherent in every human being - all share in the 
same rottenness. As all share in the image of God, so all share in the depravity of $\sin$.

Prayer had become part of her daily routine, as it expressed her intimate relationship and dependence on God. She knelt and bowed her head, because she needed to commune with God (Hillesum 2016:129). She prayed for the grace not to waste her energy on hatred for German soldiers and to cope with the stresses that her affair with Spier was submitting her to (Hillesum 2016:133-134). It was but a matter of time before she too would join the deportees at Westerbork.

The manner of her priestly or pastoral ministry at Westerbork would basically follow the same process as the therapy that she had learnt from Spier. But it was a ministry that overtly reflected her insights from her New Testament readings. She (Hillesum 2016:165, 172) meditated on the Scripture verse, 1 Timothy 2:5, about the priestly service of mediation between God and man, but added her personal corollary, 'And if God does not help me to go on, then I shall have to help God' ( $p$. 212). This statement must not be misunderstood as suggestive of a helpless God. To the contrary, she viewed her ministry as God allowing her the opportunity to serve him. God dealt with the broken and the helpless, but should they refuse the ministry of God then her ministry was to serve as God's witness in fulfilling his command to care and love her neighbour. But Hillesum (2016) also faced the reality of her commitment:

I don't fool myself about the real state of affairs, and I've even dropped the pretence that I'm out to help others. I shall merely try to help God as best I can, and if I succeed in doing that, then I shall be of use to others as well. (p. 213)

Hillesum refused to be overwhelmed by hatred debilitating her Godlike attitude to life. What was clear to her was that life has a greater meaning than the present barbarity seemed to portray. The survivors of death camps would be those who would help the world to recover its rightful balance and relationship to God. 'This theme came to be the leitmotif in all her diaries and letters' (De Costa 1998:144).

\section{Conclusion}

Hillesum neither confesses faith in Jesus Christ, nor her repentance of $\sin$. She believes in God - evidently the God of the Old Testament, and to some extent of the New Testament in whose image she is made. In obedience to these insights, she seeks to reflect that image pastorally persuading others to find the same peace and meaning of life as she did. She had a sense of God's peace - often in continuous and submissive conversation with God (Hillesum 2016:395). Accompanying that, was the deep desire to fulfil the purpose for her life to broadcast his continual presence and to dwell securely in him, confident that he will bring all things to their fulfilment (Hillesum 2016:395). It was this pastoral sense that characterises Hillesum's ministry to women at Westerbork. This is a sense of the pastoral that similarly reflects in the Reformed catechisms.

But Hillesum also seems to find a historical fit within the Christian story. She may be seen to transcend 2000 years of history and find a fit in the community of Jews in the early years of the Christian church in Jerusalem. There were communities comprising converted Jews, those in-between, being neither goose nor gander, and the anti-Christian Jews. In my opinion, she was an in-between person - one who occupied middle space, together with many of that time who gradually learnt to follow the rabbis and met with those who compiled the New Testament. From the above study it is clear that Hillesum shared in something of the substance of Christianity, but her diaries do neither allow for the fullest claims, nor the appearance of being Christian.

Hillesum was convinced that God's plan included a post-war period. ${ }^{30}$ That buttressed her purpose in life. She would mentor the women her age in Westerbork and accompany them to the end if necessary. Should she survive the war, she (e.g. Hillesum 2016:403), together with other survivors, would take it as their God-given task to broadcast the power of God and seek to ensure the creation of a great mosaic, so that the atrocities of the past would never again be repeated. That was not to be.

Both the HC and WSC catechisms do allow for more reflection. Hillesum did come to some degree of knowing God. While her journey started with introspection, her reading of the great classics brought her to an objective comprehension of God. She got to know this God more truly through reading the Scriptures of the TaNaKh and completed her discovery of God through reading the New Testament. It was from the New Testament that she learnt to love God even her Nazi enemy, and took on the responsibility of serving her neighbour practically. It was in this capacity that she left Westerbork with her girls for Auschwitz, reading Psalm 18, in particular verse 2 , and singing. ${ }^{31}$

Etty Hillesum's spiritual journey translated into a living testimony of her understanding of some of the key teachings she discovered in the New Testament. For a short period of her life, she embodied esse quam videri. ${ }^{32}$ Nevertheless, there is no safe unequivocal Reformed catechetical or confessional conclusion to come to regarding her Christian walk. Calvin (1961:568-569) exhorts Christians not to minimise the covenant of adoption, but acknowledges that the concept is open to abuse. In my opinion, it would be fair to claim some form of Christian ministry to the younger women at Westerbork, but the extent of her Christian commitment to the central tenet of the Christian faith, the Lord Jesus Christ, remains with the Judge of all the earth (Gn 18:25).

\footnotetext{
30.Some Jewish leaders encouraged their people to survive the war. Rabbi Eliezer Yitzhak Meisel from Warsaw preached that 'The greatest Kiddush Hashem will be if someone manages to stay alive.' Kiddush Hashem means 'sanctification in/of God's/the Name' and within this context centres in any act that glorifies God, but in particular when life is forfeited for his sake (Farbstein 2007:24, 26). During and immediately after the war, Jews who had died in the Shoah were referred to as kedoshim [holy ones] (could be read as 'martyrs'). But reality of survival was stark. 'The opening of the camp gates after liberation did not bring a feeling of freedom and joy; the road to physical and emotional recovery was long' (Farbstein 2007:431).

31.Trains transported an estimated number of 97776 Jewish inmates from Westerbork to Auschwitz and Sobibor death camps from July 1942 to September 1944. Most were killed upon arrival.

32.'Rather to be than to seem.' See for instance Cicero's essay 'Laelius de Amicitia' (n.d., chapter 98). Irenaeus (Adversus Haerses 4.34.5-7) said, 'The glory of God is man fully alive.
} 
For these reasons it is difficult to make an unequivocal Christian catechetical statement about Hillesum's perception of God and even less so when considering the matter of salvation in Jesus Christ. Although there is no category for a person such as Etty Hillesum in Reformed Christian catechisms and confessions, I nevertheless, wish to propose the following:

I suggest that Etty Hillesum fits into a category seldom utilised in any Christian theological system, namely that of liminal space. This reflects on the Sabbath space between the cross of Jesus on Good Friday and the resurrection of Jesus on Sunday. The space in-between Holy Saturday (Sabbatum sanctum $)^{33}$ is, in my opinion the liminal space she occupies between Good Friday and Easter Sunday - the space separating the cross and the risen Jesus. Here are no theodictic boundaries emphasising categories such as 'us' and 'them'. It is a space in which Hillesum and persons with similar experiences occupy, in their utter dependence of their Creator, the sovereign God whose grace is found in his Son. That is the space where the readers who come to the end of her diaries, leave her.

This liminal or in-between approach does allow for the fact that God's sovereign work among all persons necessitates consideration. This is a fact not clearly deduced from the HC or WSC, which famously reflects a core strand of Reformational theological thinking of salvation. But it also allows for a pastoral approach of appreciating the personal and spiritual struggles of persons who do not fit the traditional mould of church theology. This does not negate justification by faith and salvation theology. It merely brings the need to be aware of persons in congregations, who do not readily fit into our standard and expected theological categories.

\section{Acknowledgements}

I am grateful to the Pro Reformando Trust for having made it possible for me to visit the Yad Vashem during April and May 2018, where I was graciously advised by Dr. Zvi Bernhardt and assisted by his professional staff.

\section{Competing interest}

The author declares that no competing interest exists.

\section{Author's contributions}

I declare that I am the sole author of this research article.

\section{Ethical consideration}

This article followed all ethical standards for carrying out research without direct contact with human or animal subjects.

\section{Funding information}

This research received no specific grant from any funding agency in the public, commercial, or not-for-profit sectors.

\footnotetext{
33.Depending on the tradition also called Easter vigil, Easter, Great, Black or Joyous Saturday, Saturday of light, Easter Eve, or Great Sabbath.
}

\section{Data availability statement}

Data sharing is not applicable to this article as no new data were created or analysed in this study.

\section{Disclaimer}

The views and opinions expressed in this article are those of the authors and do not necessarily reflect the official policy or position of any affiliated agency of the authors.

\section{References}

Arendt, H., 1962, The origins of totalitarianism, The World Publishing Company, New York, NY

Augustin, 1886, Letters of St. Augustin in NPNF1-01, The confessions and letters of St. Augustin, with a sketch of his life and work by Philip Schaff, pp. 303-852, viewed 12 February 2019, from http://www.ccel.org/ccel/schaff/npnf101.html

Brenner, F.B, 2008, 'Etty Hillesum: A portrait of a Holocaust artist in Spirituality in the writings of Etty Hillesum', in K.A.D. Smelik, R van den Brandt and M.G.S. Coetsier, with assistance from C. Coman, D. Pevenage \& G. van Oord, (eds.) Proceedings of the Etty Hillesum Conference at Ghent University, pp. 235-251, Brill, Leiden.

Brenner, R.F., 1998, Four women confronting the Holocaust: Edith Stein, Simone Weil, Anne Frank, Etty Hillesum, The Pennsylvania State University Press, University Park, PA.

Calvin, J., 1961, Institutes of the Christian religion, vol. XX, book 1.i to iii.xix, ed. J.T. McNeill, transl. F.L. Battles, SCM Press, Ltd., London.

Cicero, n.d., 'Laelius de Amicitia', viewed 12 July 2018, from https://www.google.co.za/se arch?ei=cVBHW5ZnwahRjaiakAw\&q=cicero+laelius+de+amicitia+\%22esse+quam+vi deri\%22\&oq=cicero+laelius+de+amicitia+\%22esse+quam+videri\%22\&gs_l=psyab.12...26513.36878.0.39875.33.23.1.0.0.0.450.4413.2-5j5j3.13.0.......1c.1.64.psyab..19.7.2484...0j35i39k1j0i22i30k1j33i21k1j33i160k1.0.MBjlvpSsıro

Coetsier, M.G.S., 2010, "YOU-CONSCIOUSNESS" - Towards political theory: Etty Hillesum's experience and symbolization of the divine presence', in K.A.D. Smelik, R. van den Brandt, M.G.S. Coetsier with assistance from C. Coman, D. Pevenage \& G. van Oord (eds.), 2008 Spirituality in the writings of Etty Hillesum pp. 103-124, Brill, Leiden, Boston, MA.

De Costa, D., 1998, Anne Frank and Etty Hillesum: Inscribing spirituality and sexuality, transl. M.F.C. Hoyinck \& R.E. Chesal, Rutgers University Press, New Brunswick.

Ericksen, R.P., 2012, Complicity in the Holocaust: Churches and universities in NaziGermany, Cambridge University Press, Cambridge.

Farbstein, E., 2007, Hidden in thunder, perspectives on faith, halach and leadership during the holocaust, transl. D. Stern, vols. I \& II, Mossad Harav Kook, Jerusalem.

Foray, J.L., 2001, 'The nation behind the diary: Anne Frank and the Holocaust of the Dutch Jews', The History Teacher 44(3), 329-352.

Frame, J.M., 2002, The doctrine of God, P\&R Publishing, Phillipsburg, NJ.

Frankl, V.E., 1992, Man's search for meaning: An introduction to logo therapy, Beacon Press, Boston, MA

Friedman, S., 2004, A history of the holocaust, Valentine Mitchell, Portland, OR.

Gagné, L.B., 2000, The uses of darkness, women's underworld journeys, ancient and modern, Notre Dame Press, Notre Dame.

Hillesum, E., 2016, An interrupted life: The diaries and letters of Etty Hillesum 1941 1943, Persephone Books, London.

Hyman, P.E., 1998, 'Gender and the Jewish family in modern Europe', in D. Ofer \& L.J. Weitzman (eds.), Women in the Holocaust, pp. 25-38, Yale University Press, New Haven, CT.

Irenaeus, Adversus Haereses [Against heresies], n.d., viewed 12 September 2018, from http://www.earlychurchtexts.com/public/irenaeus_glory_of_god_humanity_ alive.htm

Kierkegaard, S., 1968, Kierkegaard's concluding scientific postscript, transl. D. Swenson \& W. Lowrie, Princeton University Press, Princeton, NJ.

Langer, L.L., 1995, Understanding atrocity: Killers and victims in the Holocaust in admitting the Holocaust: Collected Essays, Oxford University Press, Oxford.

Mansfield, K., 1988, Letters and journals, ed. C.K. Stead, Penguin Books, London.

McClelland, R.T., 2004, 'Normal narcissism and the need for theodicy', in P. van Inwagen (ed.), Christian faith and the problem of evil, pp. 185-206, William B. Eerdmans Publishing Company, Grand Rapids, MI.

McDonough, W., 2005, 'Etty Hillesum's learning to live and preparing to die: "Complacentia Boni" as the beginning of acquired and infused virtue', Journal of the Society of Christian Ethics 25(2), 179-202.

Mechanicus, P., 1968, Waiting for death, Calder \& Boyers, London.

Paas, S., 2015, Liefde voor Israël nader bekeken, Brevier Uitgeverij, Kampen.

Patterson, D., 2004, 'Through the eyes of those who were there', Holocaust and Genocide Studies 18(2), 274-290. https://doi.org/10.1093/hgs/dch065 
Pleshoyano, A.A., 2005, 'Etty Hillesum: A theological hermeneutic in the midst of evil', Literature and Theology 19(3), 221-237. https://doi.org/10.1093/litthe/ frio27

Pleshoyano, A.A., 2010, "'Spierituality" on the fringes of religious borders', in K.A.D. Smelik, R. van den Brandt \& Coetsier, Etty Hillesum's experience and symbolization of the divine presence, vol. 2, pp. 43-74, Brill Academic Publishers, Leiden

Potgieter, R., 2016, “'Israel” in biblical and Christological terms', In die Skriflig 50(1) a2104. http://dx.doi.org/10.4102/ids.v50i1.2104

Praamsma, L., 1985, Let Christ be king: Reflections on the life and times of Abraham Kuyper, Padeia Press, Ontario.

Rookmaaker, H.R., 2003, Our calling and God's hand in history: The complete works of Hans R. Rookmaaker, vol. 6, Piquant, Carlisle.
Roth, J.K., 1997, 'It started with tears', in C. Rittner \& J. Roth (eds.), From the unthinkable to the unavoidable, pp. 198-199, Greenwood Press, London.

Stark, R., 2005, The victory of reason, how Christianity led to freedom, capitalism, and Western success, Random House Trade Paperbacks, New York, NY.

Vorster, N., 2007, Restoring human dignity in South Africa: Christian anthropology in a new dispensation, Potchefstroom Theological Publications, Potchefstroom.

Wasserstein, B., 2012, On the eve: The Jews of Europe before the Second World War, Simon \& Schuster, New York, NY.

Wynn, M.R., 2005, Emotional experience and religious understanding: Integrating perception, conception and feeling, Cambridge University Press, Cambridge. 